\title{
Integrated Community Onsite Sanitation System for Close Loop Faecal Management
}

\author{
Elis Hastuti ${ }^{1,2^{*}}$, Rydha Riyana ${ }^{1}$, Benny Joy ${ }^{2}$, Unang Supratman ${ }^{2}$ and $R$ Pamekas $^{1}$ \\ ${ }^{1}$ Directorate Engineering Affairs for Human Settlements and Housing, Directorate General of Human Settlements, Ministry of \\ Public Works and Housing, Indonesia \\ ${ }^{2}$ Environment Science Program, Postgraduate School, Padjadjaran University, Indonesia
}

\begin{abstract}
The achievement of safe sanitation access is about $7.42 \%$ in 2018 , that indicates high risk of faecal contamination from unmanaged onsite sanitation system and has not been fully supported by faecal sludge service. This paper described the study of characteristic of onsite sanitation and faecal sludge for review potential of integrating of sludge handling with improved communal wastewater treatment. Faecal sludge quality were observed from pit latrines and communal septic tank, then analysis method apply cluster analysis and through close loop approach consider treatment and disposal for resource recovery. The pilot model of combined treatment of wastewater and faecal sludge was developed by anaerobic digester with a maximum 5\% sludge loading, then further treatment by biofilter system and sludge drying bed. The quality of treated water can meet COD and nitrogen as effluent standard, biosolid reached a stabilization index of $40-60 \%$, water content of 50-60\% and less Coliform bacteria content. The characteristics of faecal sludge strength to be handled will be influenced bytechnical aspect or environment. The integrated system could be applied to manage wastewater and faecal sludge and its by products, mainly for rural area has not been catered by faecal sludge service .
\end{abstract}

\section{Introduction}

The polluted water poses a severe public health hazard and environment degradation that has been caused by poor onsite sanitation system related to the lack of inadequate access to safe faecal sludge management. Although the achievement of wastewater infrastructure access in average about $74.58 \%$ in 2018 , but safe access is about $7.42 \%$ [15]. The low safe access indicates the rate of provision of wastewater infrastructure without comprehensive faecal sludge management effectively. The faecal sludge has accumulated from onsite wastewater treatment, as a mixture of partially treated sludge (or septage) and wastewater, which are rich in organic compounds and nutrients, contains disease-causing viruses, bacteria and/or parasites [19]. Impacts due to poor faecal sludge management contribute to ineffective wastewater management, that will increase problem of eutrophication, water treatment costs, decreased water recreation, health risks to humans and livestock, decreased oxygen and changes in aquatic ecosystems [7].

The Sustainable Development Goal (SDG) targets for 2030 cover adequate and equitable access to sanitation and are oriented towards increasing the effectiveness of water treatment and recycling technologies. The target of improved and safe wastewater treatment system cover onsite systems about $87 \%$ and off site systems about $13 \%$. Meanwhile, one indicator of safe access to wastewater is the management of sludge from the Wastewater Treatment Plant (WWTP). Urban and rural residential areas with a population of more than $25 \mathrm{people} / \mathrm{ha}$, are the minimum service standards for access to safe wastewater and faecal sludge services [6]. However the existing of . centralized faecal sludge treatment installation facilities have an optimal operating level of around $11 \%$, due to transportation and public awareness constraints [15].

The onsite wastewater system that dominates residential areas, most of the sludge has not been managed properly. The challenge of emptying and treatment of faecal sludge from onsite system face problems of inaccessibility or ineffective designed faecal sludge treatment and poor sanitation system. Faecal sludges are quite different from wastewater sludges, which faecal sludge can be comprised of any range of fresh excreta to products of anaerobic digestion from storage in containment, and can include soil, sand, and municipal solid waste [12]. Unscheduled desludging or emptying of sludge at WWTP will cause disruption of the removal of organic and solids in the wastewater treatment unit and part of the sludge can flow with untreated wastewater. In Citarum watershed area, as a strategic river in Indonesia, settlement area still faces the lack of improved and safe wastewater infrastructures. According to West Java Provincial Government, 2019, river pollution has been caused around $68 \%$ by domestic activities. Most of population at 1,243 villages and sub districts rely on

* Corresponding author: hastutielis@gmail.org 
site or decentralized system, almost they use pits and public containment or communal treatment. The benefits of regular emptying are reduced and improving containment should be a priority, particularly in areas dependen on shallow groundwater for water supply [10, 12]. Almost all household would not emptying regularly the sludge from these wastewater facility, however in area with high ground water table or flooding area they had often rent sludge empty services from pits These dominant faecal sludge management practices at onsite wastewater facility causes ineffectively wastewater treatment process.

The safe close loop faecal sludge management have being introducing as sustainable sanitation consists of faecal flow, wastewater technologies, sludge handling and recovering resource. The integration of wastewater and sludge treatment and management is a simple, economical and feasible choice [11]. The practice of safe close loop sanitation in Citarum's area could be a choice through integration system of wastewater and sludge and potential for reuse of resources for agriculture. The development of integrated system with a paradigm more sustainable implementation of improved close loop sanitation could face some challenges. This paper has aims to study onsite sanitation and faecal sludge characteristic for review potential of integrated system of wastewater and faecal sludge at communal scale to achieve safe close loop sanitation system or reuse oriented sanitation by recovering for agricultural purposes. The applied pilot model of integrated system combines low cost technology based on anaerobic digester, biofilm process and sludge drying bed systems.

\section{Material and Method}

\subsection{Faecal sludge characteristic in study locations}

The study locations focus on the rural housing area had existence of decentralized wastewater system, include improved communal system, community based management, and possibility for close loop faecal sludge through integration system of waste water and faecal sludge. The improved communal system was selected according to varied scheme treatment system, include anaerobic baffled reactor, biofilter system, anaerobic digester and some further treatment system. Identification of faecal sludge characteristic near these improved communal systems were observed include at pit latrines and communal septic tank (service for 2 to 10 households) and technical assessment of onsite system (cover type, construction, dimension, content, groundwater table). The observed parameter of faecal sludge was measured onsite include temperature and $\mathrm{pH}$, while chemical parameter analysis such as Biochemical Oxygen Demand (BOD), Chemical Oxygen Demand (COD), Total Suspended Solid (TSS) and Ammonium were determined according to National Standard and Standard Method -APHA 1995 at laboratory of RIHS (Research Institute for human Settlements, Ministry of Public Works and Housing).
The study locations were selected at dense rural and peri urban area in Bandung and Sumedang Regency in Java Province, as greatest area dominated in Upper Citarum Watershed, as shown in the Figure 1.

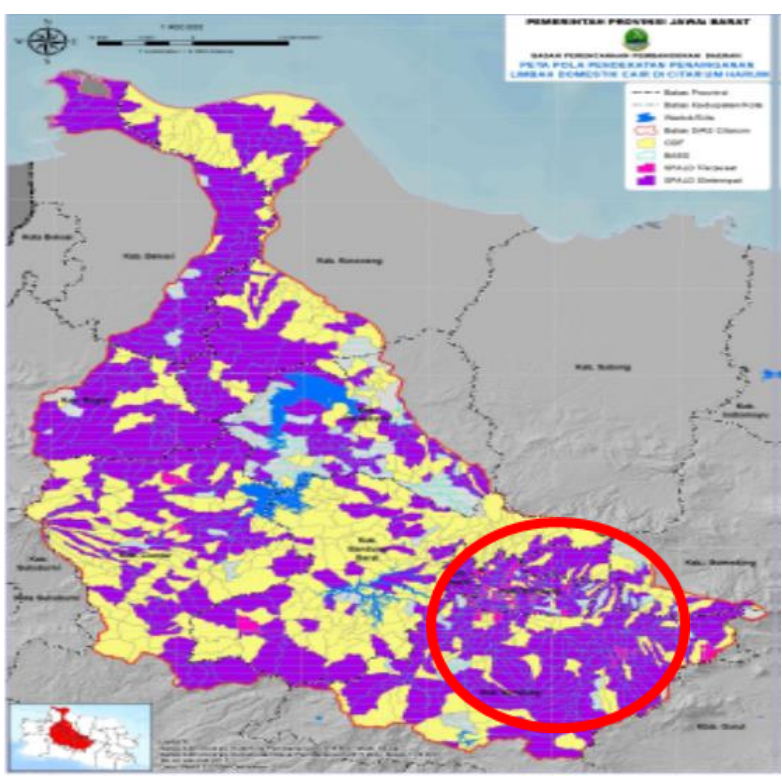

Figure 1. Study Locations of Onsite Sanitation in Upper Citarum (West Java Provincial Government, 2019)

\subsection{Design of integrated wastewater and faecal sludge system}

The potential of integrated of wastewater and faecal sludge system was analyzed through close loop approach consider treatment and disposal for resource recovery. There are reliable alternatives planning for integrated faecal sludge and wastewater treatment systems which consider characteristic onsite system and can be suggested for rural areas. The technology choices possibly covering the whole sanitation chain and existence of the demand of faecal sludge empty. The study was completed with focus on discussion of faecal sludge management with the community, involved government, which reviewed demand for emptying, impact of poor sludge disposal and planning treatment system.

\subsection{Pilot study of integrated wastewater and faecal sludge}

The study provides also a pilot scale of integrated faecal sludge and wastewater as a refer for combined treatment could be considered. The treatment systems consist of combination of upflow anaerobic digestion and biofilter system, while solid treatment applied unplanted sludge drying bed. The performance of the wastewater and faecal sludge treatment system was observed for one year after stable condition, to investigate organic, solid and nitrogen concentration in the feeding source, treated water and biosolid. The analysis pilot study includes the system performance, risks and mitigation of combined system. This pilot scale of combined treatment system in this study is small but could be a first step in faecal 
sludge research and a part of possible solution for faecal sludge management system in rural areas, consider depth analysis of different challenges, local community, sludge characteristic and site condition..

\section{Result}

\subsection{Faecal sludge disposal and treatment in rural areas}

The sustainable development according to universal access to sanitation by 2030 , is percentage of population using safely managed sanitation services which not just increasing access to toilets to reduce open defecations but also considers faecal sludge or septage management. Mostly the existing of faecal sludge management or designed location for the disposal and treatment of faecal sludge has not been catered for in both peri urban and rural area in Citarum Area. Land disposal becomes common for disposal faecal sludge and septage from onsite wastewater system. Mostly onsite facility have overflow and seepage faecal phatogens to environment that contaminated river and groundwater since the majority of community relies this water sources for clean water. However some rural areas had practiced a close loop sanitation system but appropriate sludge reuse was neglected therefore these pose risks to both public health and environment..

Table 1. Characteristic of Onsite Wastewater and Faecal Sludge Management.

\begin{tabular}{|c|c|c|c|}
\hline $\begin{array}{l}\text { Type of } \\
\text { rural } \\
\text { areas }\end{array}$ & $\begin{array}{l}\text { Onsite } \\
\text { Sanitation } \\
\text { facility }\end{array}$ & $\begin{array}{l}\text { Existing } \\
\text { Desludging } \\
\text { system }\end{array}$ & $\begin{array}{l}\text { Existing } \\
\text { treatment, } \\
\text { disposal }\end{array}$ \\
\hline $\begin{array}{l}\text { Dense } \\
\text { settlement } \\
\text { (density } \\
\text { more than } \\
200 \\
\text { population } \\
\text { /ha) }\end{array}$ & $\begin{array}{l}\text { Unlined pit } \\
\text { latrine, } \\
\text { communal } \\
\text { septic tank } \\
\text { for } 2-10 \mathrm{HH} \text {, } \\
\text { communal } \\
\text { off site for } \\
50 \text { HH } \\
\text { (ABR, } \\
\text { biofilter } \\
\text { system), } \\
\text { some } \\
\text { discharge to } \\
\text { river. }\end{array}$ & $\begin{array}{l}\text { Unschedule } \\
\text { d } \\
\text { desludging, } \\
\text { with manual } \\
\text { emptying by } \\
\text { community. }\end{array}$ & $\begin{array}{l}\text { a.Dispose } \\
\text { sludge to } \\
\text { garden, land, } \\
\text { rice field } \\
\text { b.Deep row } \\
\text { entrechment }\end{array}$ \\
\hline $\begin{array}{l}\text { Sparse } \\
\text { settlement } \\
\text { (low } \\
\text { population } \\
\text { density) }\end{array}$ & $\begin{array}{l}\text { Unlined pit } \\
\text { latrine, } \\
\text { pond or } \\
\text { discharge } \\
\text { wastewater } \\
\text { to } \\
\text { river/garden }\end{array}$ & $\begin{array}{l}\text { Develop } \\
\text { new pit } \\
\text { latrines, } \\
\text { covered the } \\
\text { old pit or } \\
\text { reuse the } \\
\text { solid. }\end{array}$ & $\begin{array}{l}\text { a.Dispose } \\
\text { sludge to } \\
\text { garden, land, } \\
\text { rice field } \\
\text { b.Deep row } \\
\text { entrechment }\end{array}$ \\
\hline $\begin{array}{l}\text { Cluster } \\
\text { settlement } \\
\text { s (compact } \\
\text { housing) }\end{array}$ & $\begin{array}{l}\text { Prevalence } \\
\text { of lined } \\
\text { ventilated } \\
\text { improved pit } \\
\text { latrine }\end{array}$ & $\begin{array}{l}\text { Mechanical } \\
\text { desludging } \\
\text { by private } \\
\text { truck }\end{array}$ & $\begin{array}{l}\text { a.Dispose } \\
\text { sludge to off } \\
\text { site } \\
\text { treatment }\end{array}$ \\
\hline
\end{tabular}

\begin{tabular}{|l|l|l|l|}
\hline & & & $\begin{array}{l}\text { b. Dispose to } \\
\text { land around } \\
\text { rice field }\end{array}$ \\
\hline $\begin{array}{l}\text { Peri urban } \\
\text { settlement } \\
\text { (near } \\
\text { highway } \\
\text { or } \\
\text { industrial } \\
\text { area) }\end{array}$ & $\begin{array}{l}\text { Lined pit } \\
\text { latrine, } \\
\text { communal } \\
\text { septic tank, } \\
\text { communal } \\
\text { off site } \\
\text { (ABR or } \\
\text { biofilter } \\
\text { system) }\end{array}$ & $\begin{array}{l}\text { Mechanical } \\
\text { desludging } \\
\text { almost every } \\
\text { year by } \\
\text { private truck } \\
\text { because of } \\
\text { high } \\
\text { groundwater } \\
\text { sludge to off } \\
\text { site area. } \\
\text { treatment in } \\
\text { Bandung } \\
\text { City } \\
\text { b. Dispose } \\
\text { sludge to } \\
\text { land around } \\
\text { rice field }\end{array}$ \\
\hline
\end{tabular}

In location study, rural communities have onsite sanitation, consists of primary form of pit latrines and communal containment. The majority of pit latrines or pits are an earth bottom, lined or unlined wall, unventilated tank that allows wastewater to seepage into the soil and sludges builds up in the bottom of the pit. This wastewater tanks pose a significantly higher risk of environmental damage than do septic tanks, are the most important sources of contamination of the groundwater [23]. While in public sanitation facility at study locations use communal containment, normally with septic tank or anaerobic baffled reactor (ABR) system. However some areas had developed improved communal system, such as submerged biofilter, rotating biological contactor or anaerobic digester system supported by goverment and private to treat wastewater that meet effluent standard and water reuse for agriculture.

According to field observation, the rural areas in Upper Citarum Watershed had onsite sanitation characteristic and faecal sludge handling, as shown at Table 1. The communities have costs limitation for regular emptying the pit or communal containment but most of them are aware of poor sanitation impact because wastewater overflowing or clogging caused bad environment and clean water pollution. While the understanding for the subsequent safe treatment and disposal faecal sludge need the gradual approach and practices. Some communities in sparse rural area can build two or more pits, each pit is used in turn when pit is nearly full condition then use other pit. The sludge from full pits disposed locally to garden or covered over for a planting area that these sludge may be partially organic or phatogen reduction. Most of communities in dense rural areas only has single pit latrines with estimated volume of 1 to $2 \mathrm{~m}^{3}$, located under the house or back yard. Problem of clogging at latrine or communal system often was solved by overflow connection from pit to river that this practices reduce the need for desludging. We observed also many houses in this village have practices to discharge wastewater from their toilet to open drain then flows to Citarum River, therefore mostly community have grealty low demand of pits or septic tank or desludging service. While some area in peri urban area or cluster settlement had manual or mechanical desludging the pits and the emptied the pis for continued use. Beside there are also compact housing area for low and middle income community in Cimanggung Village, Sumedang 
Regency, which each household uses pit latrine of volume about $1,5 \mathrm{~m}^{3}$. The existing pit never be emptied for many years but if there is clogging the toilet flow, they use mechanical desludging with vaccum truck belongs to private company, but disposed the sludge locally, or sell to farmer as soil conditioner or dispose it to sewer manhole in nearest city, Bandung City.

The classification of level of faecal sludge according to Hooijmans et al, 2013, divided by three classifications are low, medium and high strength. In the manual of planning of faecal sludge treatment published by the Indonesia's Ministry of Public Work and Housing, the level of faecal sludge has classified as high strength and low strength. High strength category has concentration of COD of 15,000-20,000 mg/L, $\mathrm{NH}_{4} \mathrm{~N}$ of $2,000-5,000 \mathrm{mg} / \mathrm{L}$, suspended solid more than $30,000 \mathrm{mg} / \mathrm{L}$ and ratio of COD to BOD is 5 . While the level of low strength has concentration of COD less than $15,000 \mathrm{mg} / \mathrm{L}$, suspended solid less than $7000 \mathrm{mg} / \mathrm{L}$ and ratio of COD to BOD less than 10. Faecal sludge in developing countries is known for its variability of physical, chemical and biological parameter, due to difference in capture and disposal mechanisms. High variations also impact on design of treatment systems to ensure uniform load into the plant especially when biological systems are preferred (Atwijukye et al, 2016).

In study location, faecal sludge characteristic was identified from onsite sanitation, including individual and communal septic tank (service for 2-10 households/HH) has content variation of solid, organic or nutrients (Table 2). The emptying and disposal of faecal sludge become a challenge due to dense settlement or inaccessibility road and unavailability of planned disposal or sludge treatment site. In general the variation of solid or organic content in study location would depend on environment, although some study show solids content of septage tends to be low, while pit latrine sludge would be higher range. The faecal sludge has very much higher solid contents than sewage, often ranging from about 2,000 to over $50,000 \mathrm{mg} / \mathrm{L}$, such as fresh sludges from public toilets will have values in the higher range [3]. It has also been observed that type of containment (i.e. pit latrine or septic tank), is a stronger predictor of physical-chemical characteristics than source (i.e. household or public toilet) $[8,13]$.

At Table 2, three locations at L1, L3 and L4 can be categorized as low level strength of faecal sludge, have COD range less than $15,000 \mathrm{mg} / \mathrm{L}$ and solid content less than $7000 \mathrm{mg} / \mathrm{L}$. In this case, containment type has less influence to organic content and solid content but may depend on retention time and environment. The sludge from pit latrines has variation of solid content, predicted depend retention time and pit location. While faecal sludge from L2 and L5, comprised of any range of fresh excreta, partly digested sludge, include soil, sand, and municipal solid waste. However it is based on index analysis of sludge quality in the Figure 2, location study at L2 and L5 due to high strength level from communal septic tank and also some pit latrines has higher index than L1, L3 or L4. The sludge collected from these area is high in BOD and $\mathrm{NH}_{4}-\mathrm{N}$ concentration that biochemically unstable.
Table 2. The Faecal Sludge Characteristic from Individual and Communal System

\begin{tabular}{|c|c|c|c|c|c|c|}
\hline Location & $\begin{array}{c}\text { Faecal sludge } \\
\text { source }\end{array}$ & BOD $(\mathrm{mg} / \mathrm{L})$ & $\operatorname{COD}(\mathrm{mg} / \mathrm{L})$ & TSS (mg/L) & $\begin{array}{c}\text { Ammonium } \\
\left(\mathrm{NH}_{4}-\mathrm{N}\right)\end{array}$ & Description \\
\hline L1 & Pit latrines & $343-857$ & $870-1,220$ & $1,211-3,012$ & $64-113$ & $\begin{array}{l}\text { Retention of } \\
2-6 \text { year }\end{array}$ \\
\hline L2 & Pit latrines & $11,094-28,450$ & $17,334-44,454$ & $5500-10,850$ & $158-188$ & \begin{tabular}{|l|} 
Retention \\
of 5-6 year
\end{tabular} \\
\hline L3 & Pit latrines & $253-987$ & $677-8,940$ & $764-1430$ & $58-63$ & $\begin{array}{l}\text { Retention of } \\
2-8 \text { years }\end{array}$ \\
\hline L4 & Drainage & $260-679$ & $2,537-11,000$ & $900-2,990$ & $47-55,6$ & \\
\hline L5 & $\begin{array}{c}\text { Communal } \\
\text { septic tank (10 } \\
\text { HH) }\end{array}$ & $33,322-49,691$ & $52,066-77,642$ & $1131-6146$ & $164-422$ & $\begin{array}{l}\text { Retention }= \\
3 \text { years }\end{array}$ \\
\hline
\end{tabular}

The index of each parameter was analyzed through cluster method consider on classification of faecal sludge level consist of ratio COD to BOD, COD, TSS and ammonia, can describe technical and complementary aspects for sludge management. The challenges in treating these faecal sludge source, both solid and liquid portion could consider the contaminant index therefore proper selection of dewatering technologies that appropriate, affordable and enforceable discharge or reuse standards. According to Gold et al, 2016; Strande, 2018, dewatering performance is likely related to physical-chemical and/or biological differences between the sludges based on demographic, environmental, and technical factors that can affect faecal sludge quality.
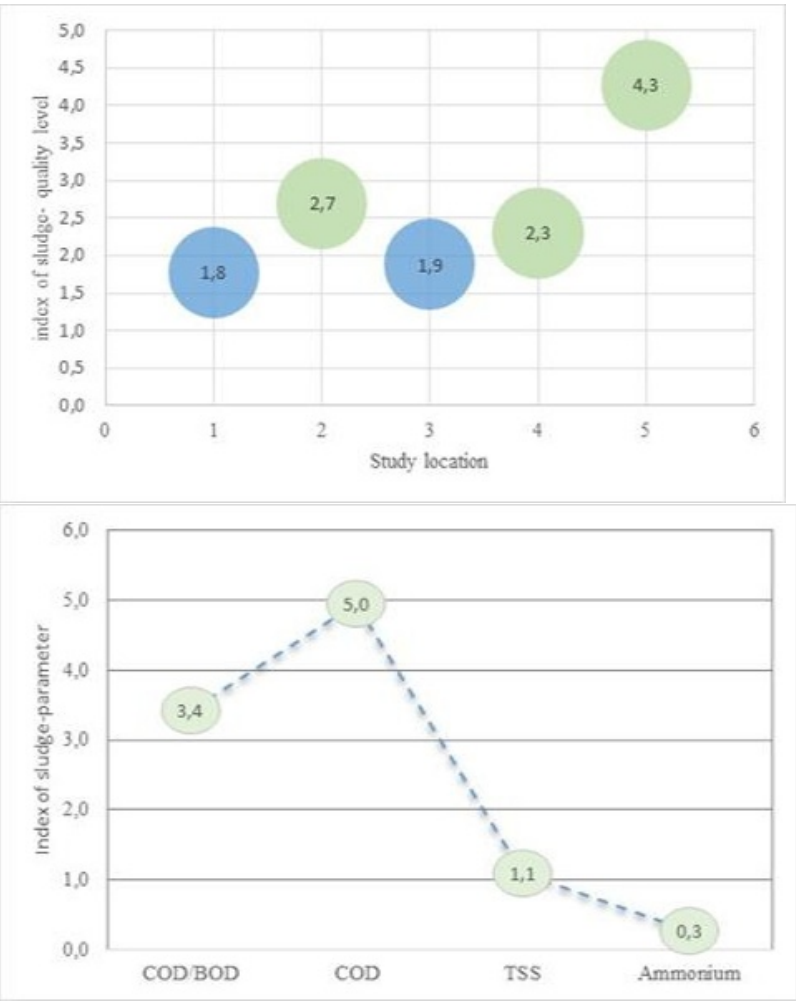

Figure 2. Index of Faecal Sludge at Study Location 


\subsection{Pilot of integrated wastewater and faecal sludge}

The integrated wastewater treatment and faecal sludge or septage treatment should be approached with caution, related to the variation of characteristics of faecal sludge. The co-treatment of faecal sludge and wastewater in anaerobic processes is an alternative for sludge stabilisation, volume reduction and increased dewaterability. Possibilities include upflow anaerobic sludge blanket reactors (UASB), anaerobic digesters and anaerobic ponds [14]. The anaerobic digester system could be an attractive benefit because the biogas production from combined system wastewater and faecal sludge. Anaerobic digestion is commonly used at wastewater treatment plant for stabilizing mixed sludge (primary and secondary waste sludge), the organic material is stabilised, thereby minimizing further biological activity, and energy rich biogas (a mixture of mainly biomethane and carbon dioxide) is produced [1].

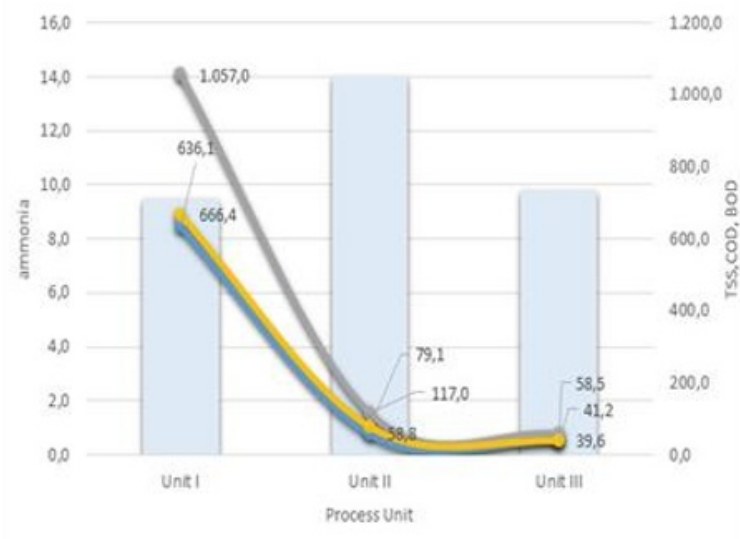

$=\operatorname{Ammonia}(\mathrm{NH} 3 \mathrm{mg} / \mathrm{L}) \rightarrow \mathrm{TSS}(\mathrm{mg} / \mathrm{L}) \rightarrow \mathrm{COO}(\mathrm{mg} / \mathrm{L}) \rightarrow \mathrm{BOO}(\mathrm{mg} / \mathrm{L})$

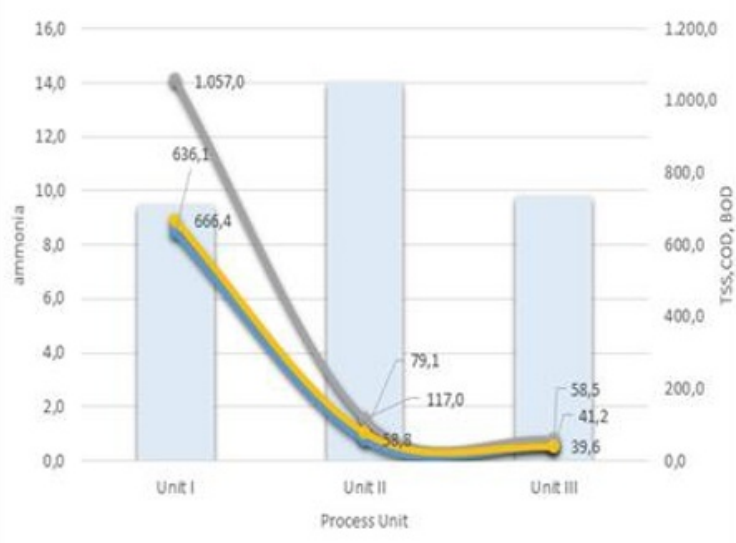

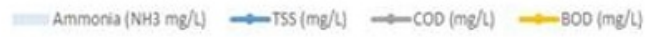

Figure 3. The Liquid Effluent Quality from Combined Treatment.
This study developed a pilot scale of anaerobic digester, designed in accordance with design criteria and principle as Metcalf and Eddy, 2003, and Still and Foxon, 2012; Strande et al, 2014. This co-treatment in anaerobic digester was applied with a maximum $5 \%$ of faecal sludge loading. Source of faecal sludge was from pit latrines in housing area of Bandung Regency (at location-L2), which has scheduled desludging because of problem of clogging and high groundwater area. The sludge has partial digested sludge may be appropriate for anaerobic co-treatment, mainly with high concentration of biodegradable organics and low solid accumulation. The faecal sludge from wet pit latrines in this location has significant fluctuation, categorized as low and high strength organic content, but low accumulation of solid.

Table 3. Biosolid quality from combined treatment.

\begin{tabular}{|l|c|c|c|c|}
\hline Parameter & unit & $\begin{array}{c}\text { Treated solid } \\
\text { from SDB }\end{array}$ & $\begin{array}{c}\text { Treated solid from } \\
\text { SDB, mixed with lime }\end{array}$ & $\begin{array}{c}\text { Standard of } \\
\text { USEPA, 2012 }\end{array}$ \\
\hline $\mathrm{pH}$ & & 7,5 & 9,2 & $50-60 \%$ \\
\hline Water content & $\%$ & 65,7 & 58 & $40-60 \%$ \\
\hline $\begin{array}{l}\text { Stabilization } \\
\text { index }\end{array}$ & $\%$ & 76,0 & 49,2 & $<1000 \mathrm{MPN} / \mathrm{s}$ \\
\hline Fecal Coliform & $\mathrm{MPN} / \mathrm{g}$ & 150,0 & $<3,6$ & $<3 \mathrm{MPN} / 4 \mathrm{gg}$ TS \\
\hline Salmonella & MPN/4 g & 23,25 & 2,3 & 1 egg L \\
\hline Yermi egg & Egg L & 30,9 & 2,4 & \\
\hline
\end{tabular}

A pilot scale system was pabricated from PVC material and metal frames, consist of anaerobic digester tank with volume of $1.4 \mathrm{~m}^{3}$. The digestate from anaerobic digester is rich in available nutrients necessary for crops, that the solid part contains less water and rich in phosphorous but most of the nitrogen stay in the liquid phase and is after separation not returned, which reduces the environmental benefits from the biogas plant system (Tornwall et al, 2017). For further treatment of digestate, applied biofilter system has volume of $0.8 \mathrm{~m}^{3}$ and a solid treatment using sludge drying bed (SDB) has area of $1.6 \mathrm{~m}^{2}$. The biofilter system has submerged media from pabricated material, while filter media at SDB was packed with coarse gravel. The faecal sludge before treated at anaerobic digester, flowed to screen and equalization tank with volume of $3 \mathrm{~m}^{3}$ and supplied gradually. The anaerobic digester was operated at the flowrate of domestic wastewater of $500 \mathrm{~L} /$ day and the feeding of low to high strength sludge was supplied gradually approximately less than $5 \%$ of wastewater flow (about $4 \mathrm{~m}^{3}$ of faecal sludge per month). The gradual supply or batch system in the combined system can avoid overloading the system $[12,14]$.

The feeding characteristic as combination of domestic waste water and faecal sludge, has a range of BOD of 500 to $1,050 \mathrm{mg} / \mathrm{L}, \mathrm{COD}$ of 667 to $1,534 \mathrm{mg} / \mathrm{L}$ and TSS of $932-1982 \mathrm{mg} / \mathrm{L}$. While the raw faecal sludge quality mostly categorized high strength quality, has COD more than $15,000 \mathrm{mg} / \mathrm{L}$ but suspended solid 
content is less than $30,000 \mathrm{mg} / \mathrm{L}$. The feeding of faecal sludge need to be operated carefully, although it was screened in the pretreatment tank but can contain much small plastic waste need to handled routinely. The result of some observation of the pilot plant performance during two years observation as shown in the Figure 3, can achieve COD and nitrogen compliance as national prescribed effluent standards $(\mathrm{COD}=100 \mathrm{mg} / \mathrm{L})$, then the effluent of biofilter system flowed to SDB unit to reduce ammonia and water content. The biosolid or treated sludge collected from SDB unit with 15 days drying duration, reached stabilization index (a ratio of volatile and non volatile) about $40-60 \%$ at case treated sludge mixed with lime, water content of 50-60\% and less Coliform bacteria content (Table 3). Other observed parameter of biosolid that can meet plant fertilizer standard, including carbon to nitrogen ratio, heavy metal content or nutrient micro content according to regulation of Agriculture Ministry number 70,2011 . The continuous co-treatment of sludge will affect the issue of non-compliance related to COD and nitrogen.Therefore the maximum septage load that a WWTP can handle without affecting its treatment efficiency should be also well known (Al-Saed and Hithnawi, 2006). In field practices, also it is important to consider socio cultural and financial implications allowing for low cost operation and maintenance.

\subsection{Potential integrated faecal sludge with improved communal wastewater system}

The degradation of Citarum Watershed environment by reentering faecal phatogens will still occur due to unproper practice of faecal sludge disposal and unscheduled sludge emptying from onsite sanitation system both individual or communal system. This sludge handling situation can cause untreated wastewater overflow from the treatment system and seepage poorly pit latrines. While it has realized in many settlement areas that the fact is sewerage system are practically non existent and limited access to Centralized Faecal Sludge Treatment Installation. Therefore to develop safe close loop sanitation, sludge treatment is required to reduce organic or phatogen for either safe disposal to the environment or reuse in agriculture. The close loop faecal sludge management that sanitation as a cycle, in which excreta are collected, transported and treated before being returned to the land as a soil conditioner or fertilizer [22]. Some approachs for faecal sludge management in rural areas will be as follows [20]:

a. Twin-pit toilets should be promoted as the preferred option for on-site faecal sludge management.

b. The appropriate technologies develop per local condition by government, system has easy to operate or maintain and low cost. Faecal sludge treatment plants will be planned for cluster of villages.

c. Co-treatment with sewage in the nearby existing sewage treatment plant will be preferred where rural areas are near urban center.

In the location study, many instalations of improved communal treatment both with or without sewerage systems developed by government or private, have no yet unscheduled desludging and some had been underutilized mainly in public sanitation facility. The combined treatment approach can be considered for integration of faecal sludge treatment from onsite system with this improved communal system therefore result less water contamination. Wastewater treatment facilities with spare capacity are a potential resource to be investigated for combined treatment or the plant has land for faecal sludge handling close to areas of demand for septage management services [4]. The study compiled some improved communal facility has variation wastewater treatment system and designed that the treated effluent meet the quality requirement for safely discharge to environment or agricultural applications (Table 3). This treatment system can be increased its performance and safely effluent discharge through proper maintenance of its sludge generation. Other sludge source that can be combined with this communal sludge, could be from pit latrines or communal septic tank nearby so that the area can have safely managed wastewater system and close loop faecal sludge. In this management, no all pits near this communal system must be regularly emptied, consider pit number must be emptied and planning collection and transportation access. The faecal sludge characteristic near this improved communal system refer to Table 2, consitst of low strength and high strength faecal sludge. Although independent treatment of faecal sludge is preferred but potential ineffective treatment process caused of uncontinue sludge feeding can be reduced.

The term integrated wastewater and faecal sludge in this study refers to treating sludge from individual and communal septic tank system with wastewater or sludge from improved communal treatment plant in strategic location and close to areas of demand for sludge services. Even co-treatment faecal sludge and communal wastewater may an option or partially liquid faecal sludge with communal wastewater could consider many factors. According to literature review and field observation, the proposed potential integrated system and technology options are shown in the Table 4. The assessment should cover both the organic and suspended solids load carried in the liquid fraction of separated sludge/septage and the volume of separated solids [10]. In case of the communal system has system of ABR and Biofilter system at L1, Table 4 and the available area still exist, the sludge from its communal system can co treatment with faecal sludge from individual system to be treated in drying area or sludge drying bed. Co-treatment faecal sludge with separated wastewater solids, although some form of digestion prior to co-treatment may be desirable to reduce odours and septage pre-treatment to separate solids from liquid. In case of the improved communal system apply biodigester system and still has available land, prior biodigestion of the faecal sludge may be advisable to reduce odour problems.

The situation of communal management by community involved are highly variable therefore the scheduled desludging time should be considered if the demand for desludging and good environment attitude have been reached. While at the location 2 and 5 (L2, L5) which has high strength of sludge level, 
pretreatment system may be applied ABR system or develop anaerobic digester at L5. In communal system at L4 had been applied vermibiofilter system, that recommended as a decentralized treatment option for use in small communities, colonies, and villages, that the effluent quality characteristics of vermibiofilter also recommended for irrigation and manure of agricultural practices, respectively (Oladoja et al, 2017). To treat the sludge from this system, could develop sludge drying bed (SDB) to dry the sludge from this system and sediment from cannal which contain faecal sludge, because almost houses surrounding this communal system flow wastewater directly to the drainage.

Table 4. The existing improved communal system and options for integrated system.

\begin{tabular}{|c|c|c|c|c|c|c|}
\hline \multirow[b]{2}{*}{ Location } & \multirow[b]{2}{*}{$\begin{array}{l}\text { Wastewater } \\
\text { treatment }\end{array}$} & \multirow[b]{2}{*}{ Capacity } & \multirow[b]{2}{*}{ Description } & \multicolumn{3}{|c|}{ Process Unit for Integrated System } \\
\hline & & & & $\begin{array}{l}\text { Solid-liquid } \\
\text { separation }\end{array}$ & $\begin{array}{l}\text { Liquid } \\
\text { fraction }\end{array}$ & Solid fraction \\
\hline L1 & $\begin{array}{l}\text { ABR, anaerobic } \\
\text { bisofilter }\end{array}$ & $50 \mathrm{HH}$ & $\begin{array}{l}\text { Idle capacity: } \\
35-40 \mathrm{HH}\end{array}$ & $\begin{array}{l}\text { Sedimentation: } \\
\text { SAR: } 0.13 \mathrm{~m}^{3} / \mathrm{m} \\
\text { of } \underline{\underline{\mathrm{SS}}, \mathrm{HRT}>4 \mathrm{~h}}\end{array}$ & $\begin{array}{l}\text { ABR or } \\
\text { bisfilter } \\
\text { system }\end{array}$ & $\begin{array}{l}\mathrm{SDB}: 100-200 \\
\mathrm{~kg} \text { TS/m²/year }\end{array}$ \\
\hline L2 & $\begin{array}{lr}\text { Hybrid } & \text { ABR- } \\
\text { anaerobic } & \text { aercokic } \\
\text { biofilter } & \end{array}$ & $=50 \mathrm{HH}$ & $\begin{array}{l}\text { Designed } 3 \% \\
\text { for sludge } \\
\text { treattrent }\end{array}$ & $\begin{array}{l}\text { Sedimentation: } \\
\text { SAR: } 0.13 \mathrm{~m}^{3} / \mathrm{m} \\
\text { of } F S, H R T>4\end{array}$ & bystem & \begin{tabular}{|l|}
$\mathrm{CW}$ for \\
250 \\
$\mathrm{TS} / \mathrm{m}^{2} /$ year
\end{tabular} \\
\hline L3 & $\begin{array}{l}\text { Anaerobic } \\
\text { Biofilter }\end{array}$ & $30 \mathrm{HH}$ & $\begin{array}{l}\text { Idle capacity: } \\
20 \mathrm{HH}\end{array}$ & & & $\begin{array}{l}\mathrm{SDB}: 100-200 \\
\mathrm{~kg} \text { TS/m²/year }\end{array}$ \\
\hline L4 & $\begin{array}{l}\text { ABR- } \\
\text { Vermibiafilter }\end{array}$ & $30 \mathrm{HH}$ & & & & $\begin{array}{l}\mathrm{CW} \text { for }<250 \\
\mathrm{~kg} \mathrm{TS} / \mathrm{m}^{2} / \text { year }\end{array}$ \\
\hline L5 & $\begin{array}{l}\text { Hybrid Anaerobis } \\
\text { digester-biofilter }\end{array}$ & $30 \mathrm{HH}$ & $\begin{array}{l}\text { Designed } 5 \% \\
\text { for sludge } \\
\text { treatroent }\end{array}$ & $\begin{array}{l}\text { HRT : } 10-20 \text { day } \\
\text { Loading rate : } 0.5 \\
1.6 \mathrm{~kg} \text { VSS } \mathrm{m}^{3} . \mathrm{d}\end{array}$ & & $\begin{array}{l}\mathrm{SDB}: 100-200 \\
\mathrm{~kg} \mathrm{TS} / \mathrm{m}^{2} / \mathrm{year}\end{array}$ \\
\hline
\end{tabular}

\section{Discussion}

The communal or individual wastewater treatment can be increased its performance and safely environment through the proper sludge treatment. Demand for desludging and its treatment from onsite sanitation may be inhibited by willingnes to pay fee desludging service, except facility problem that need to be emptied. Thus, designing management strategies for onsite rural sanitation is challenging, different schemes of sanitation services can be linked to different organizational and financing structures, institutional arrangements, social meaning, and technological processes [9]. Beside the challenge of the actual costs of transporting sludge for treatment, and financing these transport costs, are not well understood [21]. However selecting these integrated system at decentralized system can be ready solution for managing fecal sludge and septage with the requirements :

a. The improved communal watewater system designed integrated with faecal sludge from individual system, have spare capacity for sludge treatment or underutilized capacity exist therefore wastewater treatment facilities can accept faecal sludge loading. In practice, individual system in close proximity to these communal plant could potentially bring their septage to be handled at communal scale.

b. The characteristics of faecal sludge strength from onsite system dominantly low strength, therefore its treatment can combine with the sludge from communal system the high strength of septage and faecal sludge will always be advisable to solids-liquid separation of septage prior to co-treatment. Then separated liquid and solid fractions treated with wastewater and separated sewage sludge, respectively.

c. The main stakeholders within this integrated system are household level, community operator, the end -user of biosolid, and technical utility of local government. Households are responsible for capital and maintenance costs of sludge treatment facilities, and potentially some part of the costs for collection and transport additionally. Therefore sanitation education and understanding of safe faecal sludge management will be required so that key decision maker and communities believe that safe management of faecal sludge and septage is important.

\section{Conclusion}

The faecal sludge sources from onsite sanitation system in Citarum's rural areas are the predominant type from pit latrines or communal containment system. The degradation of Citarum watershed environment by reentering faecal phatogens will still occur due to unproper practice of faecal sludge disposal and unscheduled sludge emptying from onsite sanitation system. It is more challenging to develop faecal sludge or septage treatment in integrated system for irrigation and manure of agriculture that could consider some factors. The integrated system refers to treating faecal sludge or septage from individual and communal septic tank system with wastewater or sludge from improved communal treatment plant in strategic location and close to areas of demand for sludge services. The characteristic of faecal sludge strength to be handled will be influenced by technical aspect or environment. Sanitation education and understanding of safe faecal sludge management will be required that main stakeholders believe that safe management of faecal sludge or septage is important.

The integration of faecal sludge treatment with the improved communal wastewater system, could consist of treatment schemes such as anaerobic digester, biofilter system or hybrid system continued with wetland system might be devised which provide comprehensive treatment and its by-products (biosolids and liquids). To meet treatment performance, designed integrated system should consider maximum the faecal sludge load with respect to the capacity of wastewater treatment plants and the potential impacts of sludge loading rates on the efficiency and design parameter of wastewater treatment plant. This integration system at decentralized scale for safe close loop faecal sludge system and to meet SDG would need further research to study the appropriate technology options, policy 
development of faecal sludge service and stakeholder involvement.

\section{Acknowledgment}

The author would like to express gratitude to Research Institute for Housing and Human Settlements, Ministry of Public Works and Housing, as well as Local Government of West Java Province. Also, sincere appreciation has to be given to our college at Drinking Water and Sanitation Division who assist this research.

\section{References}

1. A A. Keucken, M.Habagil, D. Batstone, U. Jeppsson and M. Arnell, Anaerobic co-digestion of sludge and organic food waste-performance, inhibiton, and impact on the microbial community, Energies, 11, 2325 (2018).

2. C.M. Hooijmans, B.Dangol. C.M.Lopez Vazquez, Ronteltap, D. Brdjanovic, Assessing the feasibility of faecal sludge co-treatment in a sewage treatment plant, in the IWA Development Congress \& Exhibition, 14-17 October 2013, Nairobi, Kenya (2013).

3. D. Narayana. 2020, Co-treatment of septage and fecal sludge in sewage treatment facilities a guide for planners and implementers. London : IWA Publishing (2020).

4. D. T. G. Silva, E. Dias, J. Ebdon, H.Taylor, Assessment of recommended approaches for containment and safe handling of human excreta in emergency settings. PLOS ONE 13, 7 (2018).

5. E. Tornwall, H. Pettersson, E. Thorin, S.Scwede, Post-treatment of biogas digestate-An evaluation of ammonium recovery, energy use and sanitation, in $9^{\text {th }}$ International Conference on Applied Energy, ICAE (2017).

6. National Development Planning Agency (Bappenas), Kerangka Nasional Pengembangan Pengelolaan Lumpur Tinja. Jakarta :Bappenas dan IUWASH PLUS. (2019)

7. I.M.W. Wijaya, S.E. Soejono, Domestic Wastewater in Indonesia, Challenge in the Future related to Nitrogen Content, International Journal of GEOMATE, 15, 47 (2018).

8. J.Traber, A. Gueye, B.Diop, E. Morgenroth, $\underline{L}$. Strande, Evaluation of conceptual model and predictors of faecal sludge dewatering performance in Senegal and Tanzania, Water $\underline{\text { Research, }} 167$ (2019).

9. J.R.Mc.Conville, E.Kvarnström, J.M.Maiteki and C.B. Niwagaba, Infrastructure investments and operating costs for fecal sludge and sewage treatment systems in Kampala, Uganda, Urban Water Journal, 16, 8, 584-593 (2019).

10. K. Tayler, Faecal Sludge and Septage Treatment: A Guide for Low and Middle Income Countries. Rugby, UK : Practical Action Publishing (2018).
11. K. Rohilla, S. Luthra, B. Bhatnagar, A.Matto and U.Bhonde, Septage Management-A Practitioner's Guide. New Dehli : Center of Science and Development (2017).

12. L.Strande, M. Ronteltap, and D. Brdjanovic, Fecal Sludge Management System Approach for Implementation and Operation. London : IWA Publishing (2014).

13. L.Strande, L. Schoebitza, F.Bischoffa, D.Ddibab, F.Okellob, M.Englunda, B.J.Warda, C.B.Niwagaba, Methods to reliably estimate faecal sludge quantities and qualities for the design of treatment technologies and management solutions, Journal of Environmental Management, 223, 898-907 (2018).

14. Metcalf and Eddy, Wastewater Engineering: Treatment, Disposal, Reuse. Tchobanoglous, G., Burton, F.L. eds. New York : McGraw-Hill Book Company (2003).

15. Ministry of Public Works and Housing (Kementerian PUPR), Program dan Kebijakan Pengelolaan Air Limbah Domestik di Indonesia. Jakarta : Subdit Pengelolaan Air Limbah Domestik (2019).

16. M.Y.R Al-Saed and M.T Hithnawi, Domestic Septage Characteristics and Cotreatment Impacts on Albireh Wastewater Treatment Plant Efficiency, Engineering Sciences, 33, 2, 187-198 (2006).

17. O. Atwijukye, C. Nimanya, S. Sugden, S. Pillay, G. Otaka \& B. Pietruschka, Ensuring Availability and Sustainable Management of Water and Sanitation for All, Development of low-cost decentralized faecal sludge, treatment system for resource recovery, 39th WEDC International Conference, Kumasi, Ghana (2016).

18. Oladoja, Abiola, Nurudeen, Appropriate technology for domestic wastewater management in under-resources regions of the world, Appl. water Sci. 7 (2017).

19. P.N. Bao, M.S.Abfertiawan, P.Kumar, M.F.Hakim, Challenges and Opportunities for Septage Management in the Urban Areas of Indonesia - Case Study in Bandung City, J. Eng.Technol.Sci., 52, 4 (2020).

20. R.Verma, S. Sengupta and S. Anand, Toolkit: Managing Faecal Sludge in Rural Areas, Centre for Science and Environment, New Delhi (2020).

21. S.Balasubramanya, B.Evans, R.Hardy, R.Ahmed, A. Habib, N.S.M. Asad, M.Rahman, M.Hasan, D.Dey, L.Fletcher, M.A.C.Valero, K.C.Rao, S.Fernando, Towards sustainable sanitation management: Establishing the costs and willingness to pay for emptying and transporting sludge in rural districts with high rates of access to latrines. PLOS ONE, 12, 3 (2017).

22. S.Giltner, M.Warsono, B.Darmawan, I. Blackett, K. Tayler, Development of Urban Septage Management Models in Indonesia, Article in Waterlines, July (2013). 
23. T.Mester, D.Balla, G.Karancsl, E.Bessenyel, G.Szabon, Effects of nitrogen loading from domestic wastewater on groundwater quality, Water SA, 45, 3 (2019).

24. USEPA. Guidelines for Water Reuse. Washington : USEPA (2012).

25. West Java Provincial Government, Strategi Penanganan Limbah Domestik Sungai Citarum. Bandung : Citarum Care Action Plan 2019-2025 (2019). 